\title{
CULINARY TOURISM IN LOWER SILESIA (POLAND) IN 2014-2017
}

\author{
Aneta MAREK* \\ University of Wrocław, Institute of Geography and Regional Development, \\ Plac Uniwersytecki 1, 50-137 Wrocław, Poland, e-mail: aneta.marek@uwr.edu.pl
}

\section{Anna WIŚNIEWSKA}

Institute of Geography and Regional Studies, Pomeranian University in Słupsk, Arciszewskiego 22, 76-200 Słupsk, Poland, e-mail: anna.wisniewska@apsl.edu.p

\begin{abstract}
Citation: Marek, A., \& Wiśniewska, A. (2021). CULINARY TOURISM IN LOWER SILESIA (POLAND) IN 2014-2017. GeoJournal of Tourism and Geosites, 34(1), 226-232. https://doi.org/10.30892/gtg.34130-641
\end{abstract}

\begin{abstract}
The aim of the article is to present the culinary heritage of Lower Silesia. The quantitative and qualita tive analysis of the culinary tourism offer of 2014-2017 was performed on the basis of available source materials. It also presents the offer of regional products and awardwinning manufacturers and producers. Additionally, it indicates institutions responsible for promotion. The research shows that culinary tourism in Lower Silesia is characterized by high potential, which is evidenced by the growing number of culinary events. However, over 100 regularly organized events, numerous regional products and producers require support as well as efficient and effective promotion. The measures taken by local and regional institutions are still insufficient. Despite the rich offer, only a few events capture wider public awaren ess. There are also few events of international significance. The same applies to the producers of traditional regional products and the products themselves. The number of Lower Silesian entities belonging to the European Culinary Heritage Network is small (56). By analysing the system of nati onal and European labels and protection of regional products, it can be noticed that the Lower Silesian producers have problems overcoming the complex EU procedural obstacles. Although 48 Lower Silesian products are included on the "List of Traditional Products" of the Ministry of Agriculture and Rural Development, only one of them can boast of an EU certificate.
\end{abstract}

Key words: Lower Silesia, culinary tourism, culinary product

\section{INTRODUCTION}

Culinary tourism is an important component of cultural tourism. It plays an important role in promoting the region and shaping its image, as well as in stimulating local entrepreneurship and community integration. Culinary tourism is often associated with a specific historical or ethnographic region. It has become one of the leading segments of cultural tourism in recent years. Lower Silesia region, which is the subject of this paper, is located in the south-western part of Poland. The present Lower Silesian cuisine was shaped mainly after 1945, when a substantial part of the population was resettled on an unprecedented scale. After the Second World War, the inhabitants of the former borderland areas of Lviv, Tarnopol, Stanisławów, Polesie, Nowogródek and Vilnius settled the so-called recovered territories, including the current Lower Silesian province. As part of the same operation, the ethnic groups of Lemkos and Boykos were also displaced from their traditional lands in south-eastern Poland. A large group of those who then came to Lower Silesia were settlers from central, northern and eastern Poland. The discussed area was also inhabited by post-war Polish re-emigrants from Yugoslavia, Romanian Bukovina, France and Belgium. In 1947-1948, Lower Silesian towns became home for Greek emigrants (Szczepankiewicz-Battek, 2014). Each group brought their customs, rituals, clothes, language, as well as culinary culture to Lower Silesia. In this cultural melting pot, a cuisine that is unique, heterogeneous, highly diverse and rich in flavours has been created. The richness and diversity of Lower Silesian flavours is a unique culinary attraction of the region and an incentive for tourists to explore Lower Silesia. The diversity of the cultural heritage, especially culinary, of the discussed region is worth further presentation and analysis, hence the aim of the article is to describe the culinary heritage of Lower Silesia and to indicate culinary tourism as one of the elements of the region's promotion. The research which the article is based on was conducted in the years 2014-2017.

\section{MATERIAL AND METHODS}

One of the first definitions of culinary tourism was proposed by Long (2004). In her opinion, culinary tourism includes "intentional, cognitive participation in learning about eating patterns, participation in consumption, preparation and presentation of food, exploration of culinary and nutritional styles, and eating in a way differing from one's native ways" (Kordowska et al., 2013). In Long's perspective, culinary tourism pursues new culinary experiences, assigned to different regions. Currently, culinary tourism covers a wide range of aspects from culinary trails, to cookery classes, tasting of dishes in restaurants, to specialist literature in the form of cookbooks, cuisine guidebooks or new recipes. Culinary tourism focuses on tasting new dishes, as well as education in the cuisine of a given region or country (Long, 2004).

Wolf (2001) was also one of the first authors of the definition of culinary tourism, which he described as: "(....) travelling to find and taste ready meals and drinks" (Durydiwka, 2013). Plebańczyk (2013) distinguishes different variants of culinary tourism:

- gastronomic tourism, aimed mainly at reaching places where unique food of interest is served, e.g. restaurants;

- food tourism understood as travelling in order to visit food fairs, producers and festivals in search of flavours, tasting and buying products;

- culinary tourism, as the broadest category, including the two above concepts, and also closely related to cultural tourism and culinary heritage. This type of travelling also aims to explore local cuisine with its recipes, participate in the preparation of dishes, but also to learn about local traditions and culinary habits.

Matlovičová and Pompua (2013), on the other hand, list three distinct forms of culinary tourism where food is the primary focus of tourists' attention: gourmet, gastronomic and cuisine tourism. On a scale of degree of interest and sophistication of tourists and their tastes,

\footnotetext{
Corresponding author
} 
first comes gourmet tourism, mainly aimed at those seeking high-quality luxury food and food specialities and willing to travel because of them. The next is gastronomic tourism practised by a larger proportion of tourists looking for quality, status and prestige but willing to accept a wider range of gastronomic products. The third type of culinary tourism, cuisine tourism, is defined by tourists' wish to explore and taste local culinary specialities by visiting farmer markets, fairs, or gastronomic festivals and other events focused on specific food products or gastronomy offered by a given area (Matlovičová and Pompua, 2013). Therefore, culinary tourism is often combined in professional literature with broadly understood cultural tourism. In the opinions of many authors, culinary tourism is part of the cultural tourism in a broad sense. Cultural determinants significantly shape culinary traditions and nutrition cultures (Kowalczyk, 2008). Many tourists choose regions that are rich in culinary heritage. By eating new dishes, or experiencing a broadly understood culture of eating, tourists discover different flavours. Visiting places of this type provides tourists with knowledge about the attractiveness of the region, its traditions and social changes that have occurred over the centuries. Participation in such trips shapes culinary knowledge (Žuromskaitè and Leišienė, 2014).

Kowalczyk (2016) defines culinary tourism as tourist trips, during which the tourist has the opportunity to taste dishes and drinks, visit renowned food establishments, participate in gastronomic events, learn recipes and ways of preparing dishes, as well as the opportunity to purchase products and ingredients necessary to prepare particular dishes. The definition also encompasses tourist visits to the regions and towns that are noteworthy in the context of culinary traditions (Kowalczyk, 2016). Jędrysiak (2008) also argues that culinary tourism is part of cultural tourism. According to him, people undertaking this form of travelling seek not only culinary attractions, but als o want to broaden their knowledge. In the author's opinion, the attractiveness of a given region can be largely determined by the diversity of its cuisine and its abiding by tradition in a broad sense. Culinary tourism is now a very dynamically developing form of tourism. It is estimated that culinary tourists account for about $15 \%$ of the world's tourist traffic (Durydiwka, 2013). It is worth investigating the motives of culinary travel. According to E. Wolf, these are: searching for "ordinary" food establishments, meetings with famous people from the world of cuisine (restaurateurs, chefs), participation in cookery workshops or courses, or traveling along the so-called culinary routes (Durydiwka, 2013).

Similar elements are taken into account by Orłowski and Woźniczko (2016). In their opinion, culinary motives cover a very wide range of activities and places, but the most important of them include: participation in presentations and tastings of food products, visiting culinary museums, travelling along tourist culinary trails, participation in festivals, feasts, fetes, events, culinary competitions, culinary trainings and courses, as well as visits to restaurants, classified in gastronomic rankings, thematic taverns, inns, hostelries, auberges, wineries, places of raw materials and culinary products processing, etc. (Orłowski and Woźniczko, 2016).

Also Tomczak (2013) indicates a number of tourist attractions awaiting a culinary tourist. The most important ones include:

- places where you can taste local products and regional dishes, including shops with regional produce or organic food, inns, taverns, etc.;

- culinary events such as: culinary festivals, regional food markets, country fairs, tastings, culinary shows;

- regional products and dishes;

- people engaging in traditional manufacture of regional products, processing food according to traditional technologies.

Culinary tourism has been widely covered in literature on the subject. These issues were undertaken in the works of Grębowiec (2010), Krupa (2010); Widawski and Oleśniewicz (2014); Duda-Seifert et al. (2016); Buczkowska-Gołąbek (2017); Charzyński et al., (2017). Regional cuisine of various regions of the world was of interest to Žuromskaitè (2009); Matlovičová and Pompura (2013); Matlovičová et al. (2014); Dorocki and Struś (2015); Salanţă et al. (2015); Benkhard and Halmai (2017); Jasińska et al. (2017); Privitera et al. (2018); Kapsdorferová and Švikruhová (2019). The issues related to the promotion of culinary tourism have been dealt with by Boyne et al. (2003); Meler and Cerovic (2003); Boyne and Hall (2004); Huang (2009); Batinić (2017); Yousafab and Xiuchenga (2018). Culinary tourism is now a very dynamically developing form of tourism. It is estimated that culinary tourists account for about $15 \%$ of the world's tourist traffic (Durydiwka, 2013). The fascination with broadly understood culinary heritage, observed in recent years in the world and in Poland, can even be seen as a fashion trend, which is related to the social demand for this topic (Tomczyk-Miczka, 2011). According to Woźniczko et al. (2015) culinary tourism is one of the most important segments of tourism. Based on the review and selection of mass data and source materials, a quantitative and qualitative analysis of the offer of regional culinary tourism was performed. Among the applied methods of quantitative analyses (Denzin and Lincoln, 2009) an important part was the inventory of culinary events organised regularly in the Lower Silesia Province (Voivodeship) in 2014-2017 (Lower Silesia Culinary Events Calendar 2014-2017). The inventory was taken on the basis of source materials obtained from local government units of Lower Silesia (Marshal's Office, country offices (poviat starosty) and commune offices), local and regional tourist organisations and associations such as: country housewives club, educational farms network. The research was supplemented with conclusions from observations carried out during field research - 26 events, held regularly, were visited. During the field research, one of the methods of qualitative analysis was used, i.e. free-form interviews with the organisers of culinary tourism events. The methodology of the free-form interview is defined in-depth by Mayntz et al. (1985); Frankford-Nachmias and Nachmias (2001); Oppenheim (2004).

On the basis of data from the List of traditional products published by the Ministry of Agriculture and Rural Development (https://www.gov.pl/web/rolnictwo/lista-produktow-tradycyjnych), traditional Lower Silesian products entered on the nationwide list of traditional products were compiled. Producers of regional products who were awarded prizes in prestigious culinary competitions organised in 2014-2020 were also listed. The study also indicates institutions responsible for promoting this form of tourism. The activities of such institutions and organizations as: the European Network of Regional Culinary Heritage, the Marshal's Office of the Lower Silesian Province, the Lower Silesian Agricultural Advisory Centre, the Agricultural Market Agency, the Lower Silesian Tourist Organization, the Polish Chamber of Regional and Local Products as well as regional associations and foundations and local action groups were analysed.

The material presented in the article is a result of qualitative and quantitative research performed in the years 2014-2017 in Lower Silesia. As observed by Denzin and Lincoln (2009), "qualitative researches conduct studies in the natural environment, trying to capture sense or interpret phenomena applying terms used by the surveyed people". The research methodology of this study was selected for the purpose of accomplishing the aim of this article. The authors made use of methods of scientific literature analysis, secondary data obtained from different institutions, participant observation methods, as well as interviews conducted with participants of selected events of culinary character.

\section{RESULTS AND DISCUSION}

One of the key motivational factors of culinary tourism for tourists is perceiving it as part of cultural heritage of a touri st destination; as the connection between the past and the present through preserved tangible and intangible relics of culture - food and its variations (Matlovičová and Husárová, 2017). Having discussed the motives of tourism, it is worth presenting and evaluating the tourist offer of the Lower Silesian province. Over 100 regularly held events provide an opportunity to get acquainted with the culinary heritage of Lower Silesia. These are: country fetes, food fairs and markets, culinary festivals and feasts, picnics, competitions, gastronomic exhibitions, demonstrations of traditional food production and master chef championships (Figure 1). They feature the traditions of the region, but also foster the integration of the local community and the accumulation of experience. 


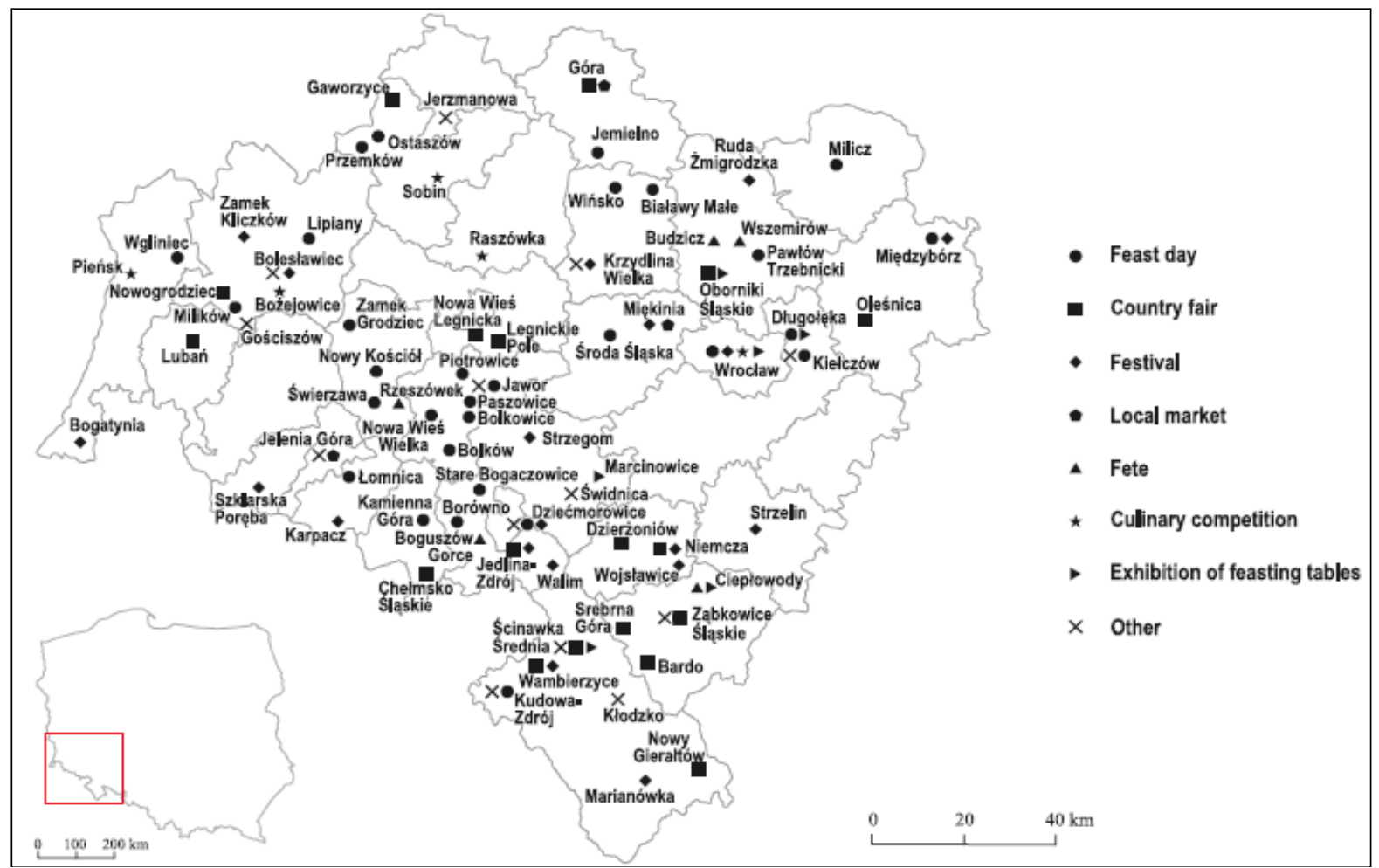

Figure 1. Inventory of regular culinary events in Lower Silesia in 2014-2017 (based on own research)

The unflagging interest of tourists led to an increase in the number of culinary events organized in the province of Lower Silesia in 20142017 from 104 in 2014 to 157 in 2017 (Table 1).

Table 1. Number of Lower Silesian culinary events in the years 2014-2017 (based on data from The Lower Silesia Culinary Events Calendar of 2014-2017)

\begin{tabular}{|c|c|c|c|c|c|c|c|c|c|}
\hline Year & Feast day & $\begin{array}{c}\text { Country } \\
\text { fair }\end{array}$ & Festival & $\begin{array}{c}\text { Local } \\
\text { market }\end{array}$ & Fete & $\begin{array}{c}\text { Culinary } \\
\text { competition }\end{array}$ & $\begin{array}{c}\text { Exhibition of } \\
\text { feasting tables }\end{array}$ & Other* & Total \\
\hline 2014 & 32 & 20 & 19 & 3 & 5 & 7 & 6 & 12 & 104 \\
\hline 2015 & 33 & 25 & 22 & 5 & 4 & 8 & 6 & 45 & 148 \\
\hline 2016 & 34 & 24 & 26 & 2 & 5 & 3 & 2 & 51 & 146 \\
\hline 2017 & 33 & 25 & 29 & 3 & 4 & 7 & 5 & 51 & 157 \\
\hline
\end{tabular}

*including picnics, fetes, fairs, workshops

Country fairs, feasts and festivals dominated in the structure of culinary events. Many events have become permanent landmarks in the Lower Silesian cultural landscape, including the Festivals of: Milicz Carp, Flour in Wrocław, Cucumber in Legnica, Honey and Wine in Przemków, Łęgi Odrzańskie in Ścinawa, Kłodzko Trout, and Eco-fair in Wrocław, as well as Our Culinary Heritage - Tastes of Regions competition, Carp Festival in Wrocław, International Bread Fair in Jawor, Easter Traditions Meetings in the Kłodzko Valley, Easter and Christmas Feasting Tables and many more. Noteworthy international events include the 'Europe on the Fork' festival in Wrocław or the International Apiary and Beekeeping Workshops in the Western Sudetes.

A guide to the culinary events of Lower Silesia is the "Calendar of Culinary Events of Lower Silesia" published regularly by the Marshal Office of the Lower Silesian province. An analysis of the culinary tourism offer of Lower Silesia reveals that the organizers of culinary events often choose themes and motifs for their events that stem from the traditions of national and ethnic minorities. The cuisine of the inhabitants of the former Eastern Borderlands, Czadca Highlanders, Lemkos, Greeks, Armenians and many other minorities can be experienced during e.g. the Our Culinary Heritage - Tastes of Regions competition held in Wrocław, the Kaleidoscope of Cultures in Wrocław, Festival of the Balkan Culture in Bolesławiec, or Pieczenica (pork roasting) in Gościszów. In Lower Silesia, numerous people and companies are engaged in the production of regional produce. Among them are the winners of the "Our Culinary Heritage" national competition held as part of the International Polagra Food Fair in Poznań. Since 2003, the "Pearl" award has been given to 39 entities from the Lower Silesian province for the presented culinary products. The winning products and producers in 2014-2017 are presented in Table 2.

Regional products are often the leitmotif of thematic villages - villages with an idea - of which worth visiting are Morzęcin Mały - a spinach village, Bagno - a herbs village, Golędzinów - a rowanberry village, Pęgów - a strawberry village, Rościsławice - a sunflower village. The dynamically operating Lower Silesian Culinary Trail called "Smaki Doln ośląskie (Lower Silesian Tastes)", associating 49 service points, is of great importance in the development and promotion of the discussed form of tourism. The trail is not linear, so tourists and event organizers can, depending on their preferences, include selected points of the trail in their sightseeing itineraries. The Trail associates entities operating in the broadly understood culinary tourism industry in Lower Silesia, which hold a qualit y certificate awarded by national or international certification organisations. Entities that do not have such a certificate are certified by a verification commission appointed by the Lower Silesian Tourist Organization (http://smakidolnegoslaska.pl/en/home/). The Trail associates restaurants and other catering establishments, hotel service facilities, retailers and associations selling traditional and regional products, regional food processors, farmers, gardeners, and fishing companies. Culinary tourism is part of a wide offer of agriculture farms. It develops particularly well in 32 farms associated in the National Network of Educational Farms (Bogusz and Wojcieszak, 2018). Half of the farms declare maintaining the tradition of regional cuisine, and 13 have prepared educational programmes related to traditional products and local cuisine. Most farms organise: shows, workshops, feasts and tastings (www.zagrodaedukacyjna.pl). 
Table 2. "Pearl" award winners from Lower Silesian province in

2014-2017 (based on data from http://www.produktyregionalne.pl)

\begin{tabular}{|l|l|l|}
\hline Year & \multicolumn{1}{|c|}{ Product } & \multicolumn{1}{c|}{ Producer } \\
\hline 2014 & Half-fat curd cheese & "DEMI Dairy Cooperative" in Góra \\
\hline 2014 & Jagodnik sausage & Dariusz Konarski \\
\hline 2014 & Mushroom soup with wild game meatballs & \multirow{2}{*}{ Ilona and Jarosław Dąbrowski } \\
\hline 2014 & Leg of mouflon & \multirow{2}{*}{ "Koniczyna" cooperative } \\
\hline 2014 & Cream of spinach soup & Adam Kudłaty \\
\hline 2014 & Rabbit saddle with spinach in its own juice & \\
\hline 2015 & Goliszów goat cheese & Ewa Migocka Honey pantry \\
\hline 2015 & Ryczyn lime tree honey & Bartłomiej Bogdański Sobótka Górka Brewery \\
\hline 2015 & Sobótka Górka 16 Beer & NOEL Henryk Nowakowski \\
\hline 2015 & Trzebnica Cider & "Cynamonowa" Kaffe Bistro Dariusz Słabicki, Dorota Słabicka \\
\hline 2015 & Lamb stewed with vegetables (dish) & Lucyna and Sylwester Wańczyk "Wańczykówka" \\
\hline 2016 & Sudeten mountain cheese & $\begin{array}{l}\text { Scinawa Fruit and Vegetable Processing Plant, Marta } \\
\text { Postoł, Teofil Szelwika, Tomasz Szelwika }\end{array}$ \\
\hline 2016 & Pickled cucumbers & Tomasz Łuszpiński, ABDITUS Ltd. \\
\hline 2016 & Karkonosze liqueur & Dworek Galosa in Strachocin \\
\hline 2016 & Wild boar and deer stew & Dar-Vit Butchery, Dariusz Konarski \\
\hline 2017 & Jagodnik cooked ham & Międzybórz Dairy Cooperative \\
\hline 2017 & Traditional butter & "Honey by Turek" Apiary, Maciej Turek \\
\hline 2017 & Niemcza forest honey & Elżbieta Malinowska, Beekeeping Farm \\
\hline 2017 & Marrons & \\
\hline
\end{tabular}

Lower Silesia as a region promotes its products and regional dishes. The most recognizable are: blueberries in Chocianów, dumplings (pierogi) in Paszowice, bread in Jawor, honey in Przemków and Oleśnica, wine in Środa Śląska, trout in the Kłodzko Valley, carp in Milicz, curd cheese in Międzybórz, cheese in Dziećmorowice, chocolate in Świebodzice, soup in Jedlina Zdrój, lamb in "Kowalowe Skały" or goose meat in Kudowa Zdrój. Traditional Lower Silesian products entered on the "List of Traditional Products" of the Ministry of Agriculture and Rural Development were divided into 9 categories (Table 3). Country Housewives' Clubs also play a significant role in promoting culinary tourism. On their initiative or with their participation, events are organized during which the culinary traditions of the region are presented, such as harvest festivals, fairs, Christmas events.

Table 3. Traditional Lower Silesian products on the "List of Traditional Products" (based on data from http://www.minrol.gov.pl)

\begin{tabular}{|l|l|}
\hline \multicolumn{1}{|c|}{ Category } & \multicolumn{1}{c|}{ Products } \\
\hline Dairy products & Blue cheese, the Sudetes curd cheese, cheeses of Kamienna Góra, Zgorzelec, Łomnica goat cheese \\
\hline Meat products & $\begin{array}{l}\text { Zacisze roasted pig, Niemcza pickled fatback, Niemcza home-made meat pieces, Niemcza pork ham, Volhynia-style relish of } \\
\text { Niemcza, Przedgórze Sudeckie sausage in jar, Niemcza sausage, Niemcza galicjanka sausage }\end{array}$ \\
\hline Fish products & Milicz carp, Klodzko trout, smoked Kłodzko trout \\
\hline Fruit and vegetables & The Barycza Valley raspberry syrup, Ślęża sauerkraut, Slęża sour cucumbers, Ścinawa pickled cucumbers \\
\hline $\begin{array}{l}\text { Bakery and } \\
\text { confectionery } \\
\text { products }\end{array}$ & $\begin{array}{l}\text { Pomocne home rye bread, Pomocne wheat-rye souerdough bread, Przemków honey gingerbread biscuits, Oleśnica wheat-rye } \\
\text { gingerbread cakes, kolach of Kuty Armenians, Rogowo Sobóckie rustic bread, crumble topping cake of Kłodzko region, Gogołowice } \\
\text { bread, begle (jumbals) }\end{array}$ \\
\hline Oils and fats & Traditional butter \\
\hline Honey & $\begin{array}{l}\text { The Sudetes buckwheat and multiflower honey, the Barycza Valley multiflower honey, the Ząbkowice region lime tree set honey, } \\
\text { Ryczyn lime tree honey, Bory Dolnośląskie heather honey }\end{array}$ \\
\hline $\begin{array}{l}\text { Ready dishes and } \\
\text { meals }\end{array}$ & $\begin{array}{l}\text { Chrząstawa potato and curd cheese dumplings (pierogi), rabbit pate with spinach, Spytków goose stuffed with pancakes, Krużewniki } \\
\text { black cabbage rolls, Silesian relish (pork dish), keselica (sourdough soup) }\end{array}$ \\
\hline Drinks & Książęce beer of Lwówek, Lutynia pressed apple juice, Trzebnica cider, Karkonosze mountains liqueur, Silesian wine, Juha-dried fruit compote \\
\hline
\end{tabular}
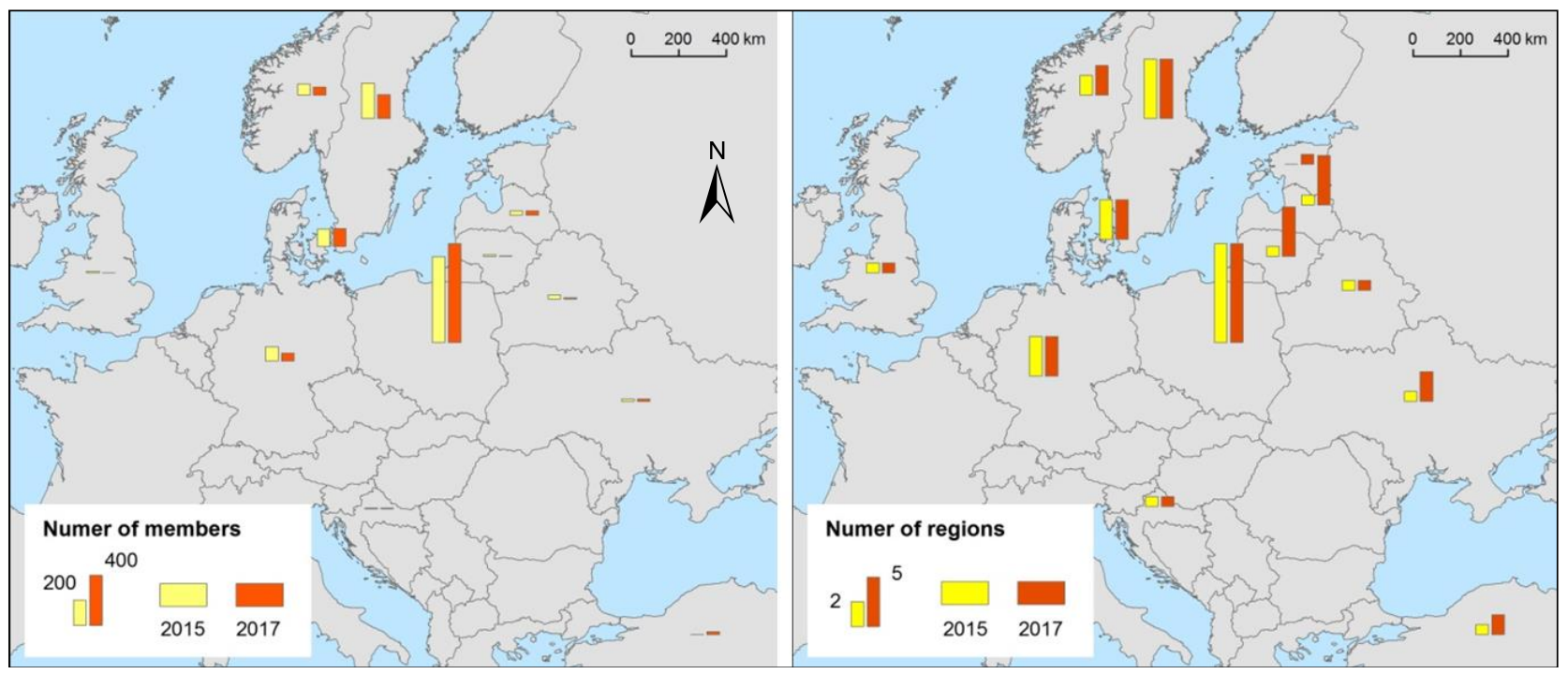

Figure 2. Numbers of members and approved regions of the European Network of Regional Culinary Heritage in 2015 and 2017 (Prepared by the authors based on data from http://www.culinary-heritage.com/regions.asp)

The promotion of the culinary heritage of Lower Silesia is handled by many organizations and institutions. One of the most important ones is the European Network of Regional Culinary Heritage, which brings together 33 European regions (Figure 2), aimed at joint development through regional food and culinary traditions (Jęczmyk et al., 2014). The first Polish region to join the Network in 2005 was the Warmian-Masurian province. In subsequent years, other provinces joined the Network (Table 4). In 2016, 10 provinces (673 entities) were members of the organization. The network logo - a white cook hat on a blue background has become synonymous with high quality products produced in a traditional way while preserving the tradition of the region (Świtała-Trybek, 2014). On June 10, 2011, the Lower Silesia province became a certified member of the Network. The Network logo and the wording Lower Silesia Culinary Heritage can be found at the entrance to many restaurants, processing plants or shops, which are inspired by a common idea: respect for tradition and high quality of offered products. By the efforts of the Polish Chamber of Regional and Local Produce, the national "Quality and Tradition" system was established for promotional purposes. Its aim is to recognise high-quality food products with a traditional character or with characteristics 
that distinguish them from other products of the same category, and which have the producer's assurance of their unique features or maintenance of higher production standards (Jęczmyk and Sammel, 2012). All the described activities aim at protecting traditional and regional

Table 4. Provinces members of the European Network of Regional Culinary Heritage (based on data from http://www.culinary-heritage.com/regions)

\begin{tabular}{|r|l|c|c|}
\hline No & \multicolumn{1}{|c|}{ Province } & Joined in & Number of members \\
\hline 1 & Lower Silesian & 2011 & 56 \\
\hline 2 & Kuyavian-Pomeranian & 2012 & 39 \\
\hline 3 & Lesser Poland & 2014 & 12 \\
\hline 4 & Masovian & 2008 & 67 \\
\hline 5 & Opole & 2008 & 56 \\
\hline 6 & Pomeranian & 2008 & 63 \\
\hline 7 & Świętokrzyskie & 2010 & 68 \\
\hline 8 & Warmian-Masurian & 2005 & 156 \\
\hline 9 & Greater Poland & 2008 & 116 \\
\hline 10 & West Pomeranian & 2008 & 40 \\
\hline
\end{tabular}
In order for a product to receive the PGI label, at least one of the production stages has to take place in the area to which its name refers. In Poland, until 2017, this label was awarded to 16 products, including one from Lower Silesia - heather honey from Bory Dolnośląskie. This product is characterized by an exceptionally high content of heather pollen and other unique components (http://www.produktytradycyjne.pl/offer/cert/chog/page/2. The Traditional Specialty Guaranteed label is awarded to products bearing a name that refers to the tradition of this product or its unique character. The product marked with this sign should have been produced from generation to generation (Grębowiec, 2010). The TSG mark can be given to agricultural products intended for consumption or finished products such as drinks from plant extracts, bread, beer, confectionery products, chocolate products, pasta and ready dishes. In Poland, this mark was awarded to 8 traditional products by 2017. Among them there are none from Lower Silesia. The Polish Chamber of Regional and Local Product is another organization which promotes the culinary heritage of Lower Silesia, and awards the "Pearl" prize. This organization's involvement in promoting regional produce resulted in establishing the national "Quality and Tradition" system. This institution acknowledges high quality food products, including these from Lower Silesia, distinguished by traditional character or features that differentiate them from other products of the same category, and holding the manufacturer's assurance of exceptional features of this product or maintaining higher production standards (Jęczmyk and Sammel, 2012). It is worth noting that the Regional Branch of the Polish Chamber of Regional and Local Product operates in Lower Silesia.

Table 5. Selected promotional activities of local and regional institutions supporting the culinary heritage of the Lower Silesia region in 2014 (based on Wabnic, 2015 )

\begin{tabular}{|c|c|c|c|}
\hline \multirow{2}{*}{ Institution } & \multirow{2}{*}{ Form of promotion } & \multicolumn{2}{|l|}{ Example material } \\
\hline & & Title & Volume \\
\hline \multirow{2}{*}{$\begin{array}{l}\text { Marshall Office } \\
\text { Division of Rural Areas }\end{array}$} & Calendars & Culinary Events of Lower Silesia & 2000 \\
\hline & Catalogues & Regional and Traditional Products of Lower Silesia & 1500 \\
\hline \multirow{2}{*}{$\begin{array}{l}\text { Lower Silesian Branch Office of Agricultural } \\
\text { Advisory Centre }\end{array}$} & Leaflets & European Culinary Heritage Network & 1000 \\
\hline & \multirow{2}{*}{ Brochures } & Lower Silesian Vineyards & 100 \\
\hline Lower Silesian Tourist Organisation & & Traditional Regional Products of Lower Silesia & 4000 \\
\hline \multirow{3}{*}{$\begin{array}{l}\text { The Barycza Valley } \\
\text { Local Action Groups }\end{array}$} & Calendars & Regional Products & 500 \\
\hline & Calendars & Recipes & 500 \\
\hline & Catalogues & Carp Festival & 20000 \\
\hline \multirow{3}{*}{$\begin{array}{l}\text { Kłodzka Wstęga Sudetów } \\
\text { Local Action Groups }\end{array}$} & Information folders & Lower Silesian Flavours & 1000 \\
\hline & Leaflets & Lower Silesian Flavours & 500 \\
\hline & Publishing house & Lower Silesian Flavours - Recipes & 600 \\
\hline \multirow{2}{*}{$\begin{array}{l}\text { Bory Dolnośląskie } \\
\text { Local Action Groups }\end{array}$} & \multirow{2}{*}{ Posters } & Award winning dish of the „Ale Pasztet” Culinary Competition & 250 \\
\hline & & Promotion of the „Ale Pasztet" Festival & 100 \\
\hline
\end{tabular}

The culinary heritage of the region is supported at the national level by entering the product into the "List of Traditional Products" of the Ministry of Agriculture and Rural Development (Act of December 17, 2004, Journal of Laws of 2005 No. 10, item 68). The evaluation criteria are quality and traditional production methods that have been used for at least 25 years. The benefits of placing the product on the Ministry List include greater interest in the product itself and also in the region it comes from and an increase in its market value (Krupa, 2010).

The list currently encompasses 1650 products, 47 of which are from Lower Silesia. Products representing the Lower Silesia province account for only $2.8 \%$ of Polish traditional produce (Wabnic, 2015). However, in the European system of traditional products protection there is only one Lower Silesian product - the heather honey from Bory Dolnośląskie (Protected Geographical Indication certificate). Culinary events are often used to create the image of the region. Properly used in promotion, they can be an important element of the message about the attractiveness and uniqueness of the tourist region (Bienia et al., 2014). The offer of Lower Silesian culinary tourism can also be found in widely distributed nationwide guidebooks and brochures issued by the Agricultural Market Agency entitled Following the Trail of Good Taste (Szlakiem dobrego smaku) (volume: 32330 guides and 50,000 brochures). The promotion of culinary tourism of Lower Silesia is, however, primarily supported by provincial and local level authorities, i.e. the Marshal's Office, the Lower Silesian Agricultural Advisory Centre, the Lower Silesian Tourist Organization, as well as associations and foundations, and local action groups. The main platform of communication with tourists and others interested in culinary tourism are the websites of the above-mentioned organizations. For the promotion of the region's offer, these entities also use printed materials (Table 5). Although local and self-government authorities see culinary tourism as an excellent opportunity to promote the region and actively strive to support it, this activity should be intensified. Only a few events or regional products are more widely identified with the region. It is only the capital of the province, the city of Wrockaw, that stands out positively against the background of the region, i.e. various culinary events thrive there, being promoted by tourist and local government institutions and developed under the patronage of famous people (e.g. Robert Makłowicz). This phenomenon is confirmed by the research of Duda-Seifert et al. (2016) and Woźniczko and Orłowski (2017). However, in other parts of Lower Silesia, such events remain merely local in character. In the opinion of the organisers of culinary events, the promotion provided is insufficient. Information about planned events is directed mainly to local communities via websites and social media, whereas the costly, though effective, promotional campaign on banners, posters, in the media, such as radio and television is limited. The authors' observations show that there is a lack of appropriate activities aimed at tourists. The organisers of culinary events do not promote their offer among the owners of accommodation facilities. 


\section{CONCLUSIONS}

As a result of population exchange after 1945, Lower Silesia is a multicultural and diverse region. According to Duda-Seifert et al. (2016), typical Lower Silesian dishes are still poorly recognizable. This stems from historical events (population exchange), during which the cultural continuity of Lower Silesia was interrupted. Hence, Lower Silesian cuisine, which in a way has been reconstructed from scratch, draws from the flavours and cuisines of other regions and countries, including Silesian, German, Ukrainian, Lemko, Czech and other traditions. Research shows that culinary tourism in Lower Silesia has a vast potential - as evidenced by the growing number of culinary events such as country fetes, food fairs and markets, culinary festivals and feasts, picnics, competitions, gastronomic exhibitions, demonstrations of traditional food production and master chef championships. The wide offer of the region includes, among others 100 regularly organized events and 49 certified points associated in the dynamically developing Lower Silesian Culinary Trail "Smaki Dolnośląskie". Many events have become a permanent part of the Lower Silesian cultural landscape, including the Festivals of: Milicz Carp, Flour in Wrocław, Cucumber in Legnica, Honey and Wine in Przemków, Carp Festival in Wrocław, Kłodzko Trout Festival, Eco-fair in Wrocław as well as Our Culinary Heritage - Tastes of Regions competition. Numerous regional products, including forest honey from Niemcza, Milicz carp or Karkonosze mountains liqueur win prizes in national competitions and shows.

It is noteworthy that culinary tourism is part of the wide offer of Lower Silesian agriculture farms. It develops particularly in 32 farms associated in the National Network of Educational Farms, offering educational programmes related to regional cuisine, tastings, culinary workshops and folk feasts. Educational farms, agritourism farms and country housewives' clubs are important entities cultivating the culinary traditions of the region. An analysis of the system of national and European labelling and protection of regional products reveals that although 48 traditional products from Lower Silesia are entered on the "List of Traditional Products" of the Ministry of Agriculture and Rural Development, only one of them (Heather Honey from Bory Dolnośląskie) has an EU certificate. Producers in Lower Silesia have a problem with overcoming the obstacles of complex EU procedures. Similar is the case of the manufacturers of traditional regional products and with the products themselves. The number of Lower Silesian entities belonging to the European Network of Culinary Heritage is small (56). The benefits of this membership are worth promoting. Another problem is the low recognisability of the organisation's logotype.

Despite the rich offer of culinary tourism in Lower Silesia, only a few events reach wider public awareness. Most of them are poorly recognisable even in the region. There are also few events of international significance - the exceptions are the International Bread Fair in Jawor, the 'Europe on the Fork' festival in Wrockaw or the International Apiary and Beekeeping Workshops in the Western Sudetes. The potential resulting from the region's near-border location also remains untapped. The neighborhood of the Czech Republic offers additional opportunities for establishing cooperation in the organisation and promotion of culinary events.

The offer of culinary tourism in Lower Silesia requires support and efficient, effective promotion carried out on many levels. The most involved entities in this area are the Marshal's Office, the Lower Silesian Agricultural Advisory Center, the Lower Silesian Tourist Organization, as well as associations and foundations and local action groups. The main platform for communication with tourists and all interested in culinary tourism are the websites of the above organizations and promotional materials, such as leaflets, guidebooks and thematic brochures. The promotion of culinary tourism takes place mainly on a local and regional scale, there are few coherent national and international campaigns. The only exception is the city of Wrocław, where the promotion of festivals is very strong. The International Bread Fair in Jawor, Easter Traditions Meetings in the Kłodzko Valley, Easter and Christmas Feasting Tables and many other are worth promoting. Due to the vast potential of the culinary heritage of Lower Silesia, it can be concluded that measures for the development of culinary tourism require a consistent strategy and cooperation on many levels. Cooperation between organisers of culinary events, producers of regional products, owners of tourist facilities (mills, apiaries, farms), and local government administration and institutions established for the development of tourism in the region is vital. Joint activities should be aimed at creating a brand that attracts tourists and investors.

\section{REFERENCES}

Batinić, I. (2017). The role and importance of promotion in the development of gastronomic tourism of the Republic of Croatia. Journal of Process Management - New Technologies, 5(3), 87-91. https://doi:10.5937/jouproman5-14549

Benkhard, B., \& Halmai, M. (2017). Mouthful Hungary - overview of Hungarian cuisine and culinary tourism. Geography and Tourism, 5(1), 41-54. https://doi:10.5281/zenodo.834495

Bienia, B., Sawicka, B., Dykiel, M., Krochmal-Marczak, B., Pisarek, M., Betlej, I., \& Borkowska, H. (2014). Promocja żywności tradycyjnej na Podkarpaciu [Promotion of traditional food in Podkarpacie]. In Zarzecka, K. \& Kondracki, S. (eds.), Wspótczesne dylematy polskiego rolnictwa [Contemporary dilemmas of polish agriculture]. pp. 47-55, Państwowa Szkoła Wyższa im. Papieża Jana Pawła II, Biała Podlaska, Poland.

Bogusz, M., \& Wojcieszak, M. (2018). Zagrody edukacyjne jako przykład markowego produktu turystyki wiejskiej [Educational farms as an example of a branded product of rural tourism]. Intercathedra, 4 (37), 329-334 (in Polish).

Boyne, S., Derek, H., \& Williams, F. (2003). Policy, Support and Promotion for Food-Related Tourism Initiatives. Journal of Travel \& Tourism Marketing, 14(3), 131-154. https://doi:10.1300/J073v14n03_08

Boyne, S., \& Hall, D. (2004). Place promotion through food and tourism: Rural branding and the role of websites. Place Branding, 1(1), 80-92. https://doi: $10.1057 /$ palgrave.pb.5990007

Buczkowska-Gołąbek, K. (2017). Regional Culinary Heritage Europe network as a factor of culinary tourism development - Wielkopolska Region (Greater Poland) case study. Geography and Tourism, 5(1), 19-29. https://doi:10.5281/zenodo.829559

Charzyński, P., Łyszkiewicz, A., \& Musiał, M. (2017). Portugal as a culinary and wine tourism destination. Geography and Tourism, 5(1), 87-102. https://doi:10.5281/zenodo.834518

Denzin, N.K. \& Lincoln, Y.S. (2009). Metody badań jakościowych [Sage handbook of qualitative research]. PWN, Warszawa, Poland.

Dorocki, S., \& Struś, P. (2015). Regionalne zróżnicowanie turystyki kulinarnej na terenach wiejskich Francji [Regional differences in culinary tourism in rural areas of France]. Turystyka Kulturowa, 7, 6-17, (in Polish).

Duda-Seifert, M., Drozdowska, M., \& Rogowski, M. (2016). Produkty turystyki kulinarnej Wrocławia i Poznania - analiza porównawcza [Culinary products of Wroclaw and Poznan - comparative analysis]. Turystyka Kulturowa, 5, 101-114 (in Polish).

Durydiwka, M. (2013). Turystyka kulinarna - nowy (?) trend w turystyce kulturowej [Food tourism - a new (?) trend in cultural tourism]. Prace i Studia Geograficzne, 52, 9-30 (in Polish).

Grębowiec, M. (2010). Rola produktów tradycyjnych i regionalnych w podejmowaniu decyzji nabywczych przez konsumentów na rynku dóbr żywnościowych $w$ Polsce [The role of traditional and regional products in consumer decisions in retail food market in Poland]. Zeszyty Naukowe Szkoły Głównej Gospodarstwa Wiejskiego, 10 (2), 22-31, (in Polish).

Huang, R. (2009). The role of food in promoting Chinese regions on the web. International Journal of Tourism Policy, 2(4), 289-305. https://doi: 10.1504/IJTP.2009.028715

Frankfort-Nachmias, Ch., \& Nachmias, D. (2001). Metody badawcze w naukach społecznych [Research Methods in the Social Sciences]. Wyd. Zysk i S-ka, Poznań, Poland.

Jasińska, J., Charzyński, P., \& Świtoniak, M. (2017). Potential for the development of culinary tourism in Zambia. Geography and Tourism, 5 (1), 103-113. https://doi:10.5281/zenodo.834524

Jęczmyk, A., Maćkowiak, M., \& Uglis, J. (2014). Dziedzictwo kulinarne elementem przewagi rynkowej w ofercie gospodarstw agroturystycznych [Culinary heritage as an element of market advantage in agritourism business]. Roczniki Naukowe, XVI (2), 103-108 (in Polish). 
Jęczmyk, A., \& Sammel, A. (2012). Ochrona tradycyjnych produktów regionalnych jako czynnik rozwoju turystyki kulinarnej [The culinary tourism and the need for the protection of traditional regional products]. Ekonomiczne Problemy Turystyki 4. Zeszyty Naukowe Uniwersytetu Szczecińskiego, 738, 217-228, (in Polish).

Jędrysiak, T. (2008). Turystyka kulturowa [Cultural Tourism]. Polskie Wydawnictwo Ekonomiczne, Warszawa, Poland.

Kapsdorferová, Z., \& Švikruhová, P. (2019). The potential of the food tourism of traditional dairy products in Slovakia. Interdisciplinary International Conference on 'Tourism, Management and Development of Territory', Bari, 373-370.

Kordowska, M., Kowalczyk, M., \& Kulczyk, S. (2013). Smakowanie natury - o przyrodniczych korzeniach turystyki kulinarnej [Tasting nature - the natural roots of culinary tourism]. Prace i Studia Geograficzne, 52, 31-45 (in Polish).

Kowalczyk, A. (2008). Współczesna turystyka kulturowa - między tradycją a nowoczesnością [Contemporary cultural tourism - between tradition and modernity]. In Turystyka kulturowa. Spojrzenie geograficzne, (pp. 9-57), Uniwersytet Warszawski, Warszawa. (in Polish).

Kowalczyk, A. (2016). Turystyka kulinarna - podejścia 'geograficzne' $i$ 'niegeograficzne' [Culinary tourism - geographical' and 'non-geographical' approaches]. Turystyka Kulturowa, 5, 29-59 (in Polish).

Krupa, J. (2010). Dziedzictwo kulinarne elementem atrakcyjności turystycznej region [Culinary heritage as an element of tourism attractiveness of the region]. Problemy Ekologii Krajobrazu, 27, 451-455 (in Polish).

Long, L.M. (2004). Culinary tourism. Lexington. University Press of Kentucky. The United States of America

Matlovičová, K., \& Pompura, M. (2013). The Culinary Tourism in Slovakia Case Study of the Traditional Local Sheep's Milk Products in the regions of Orava and Liptov. GeoJournal of Tourism and Geosites, Oradea - Gdańsk, VI, 2(12), 129-144.

Matlovičová, K., Kolesárová, J., \& Matlovič, R. (2014). The use and stimulation of culinary tourism in learning about local and regional cultural peculiarities and historical heritage. In Faracik, R. (ed.), Enhancing competitiveness of V4 historic cities to develop tourism. Aspects of cultural heritage (pp. 141-164), Krakow-Debrecen (Poland-Hungary).

Matlovičová, K., \& Husárová, M. (2017). Heritage marketing a možnosti jeho využitia pri rozvoji turistickej destinácie. Prípadová štúdia hradu Čičva. Folia Geographica, 59(1), 5-35

Matlovičová, K., Tirpáková, E., \& Mocák, P. (2019). City Brand Image: Semiotic Perspective. A Case Study of Prague. Folia Geographica, 61(1), 120 -142.

Mayntz, R., Holm, K. \& Hubner, P. (1985). Wprowadzenie do metod socjologii empirycznej [Einführung in die Methoden der empirischen Soziologie], Państwowe Wydawnictwo Naukowe, Warszawa, Poland.

Meler, M., \& Cerovic, Z. (2003). Food marketing in the function of tourist product development. British Food Journal, 105(3), 175-192. https://doi:10.1108/00070700310477121

Oppenheim, A.N. (2004). Kwestionariusze, wywiady, pomiary postaw [Questionnaire design, inteviewing and attitude measurement], Wyd. Zysk i S-ka, Poznań, Poland.

Orłowski, D., \& Woźniczko, M. (2016). Turystyka kulinarna w Polsce - wstępne badania nad fenomenem zjawiska [Culinary tourism in Poland - preliminary research on the phenomenon]. Turystyka Kulturowa, 5, 60-100, (in Polish).

Plebańczyk, K. (2013). Turystyka kulinarna w kontekście zrównoważonego rozwoju w kulturze - perspektywy dla Polski [Culinary tourism in the context of sustainable development in the culture - perspectives for Poland]. Turystyka Kulturowa, 10, 23-38, (in Polish).

Privitera, D., Nedelcu, A., \& Nicula, V. (2018). Gastronomic and food tourism as an economic local resource: Case studies from Romania and Italy. GeoJournal of Tourism and Geosites, 21(1), 143-157.

Salanță, L.C., Păucean, A., Tofană, M., Man, S., \& Pop, C. (2015). Romanian cuisine: culinary habits and local produce. Journal of Agroalimentary Processes and Technologies, 21(2), 186-191.

Sava, C., Karabašević, D., \& Cleşiu, S.R. (2019). Culinary tourism - a reality of our days. Quaestus, 14, 269-278.

Szczepankiewicz-Battek, J. (2014). Osadnictwo i ludność w Sudetach z perspektywy geografii historycznej [Settlement and population in the Sudetes from the perspective of historical geography]. In Marek, A. \& Olszak, I.J. (eds.), Sudety i Przedgórze Sudeckie. Środowisko, ludność, gospodarka [The Sudetes and Sudetes foothills. Environment, population, economy]. pp. 263-312, Silesia, Wrocław, Poland.

Świtała-Trybek, D. (2014). Dziedzictwo kulinarne w kontekście europejskiego ruchu turystycznego [Culinary heritage in the context of European tourism]. Studia Etnologiczne i Antropologiczne, 14, 28-43, (in Polish).

Tomczak, J. (2013). Szlak kulinarny jako przykład szlaku tematycznego [A culinary trail as an example of a theme trail]. Prace i Studia Geograficzne, 52, 47-62, (in Polish).

Tomczyk-Miczka, E. (2011). Dziedzictwo kulinarne elementem tworzenia marki regionu [Culinary heritage as an element of creating a region's brand]. In Orłowski, D. \& Wylężałek, J. (eds.) Związki polskiego dziedzictwa kulturowego z turystyką [Connections of Polish cultural heritage with tourism]. pp. 255-275, Wyd. Wyższa Szkoła Turystyki i Języków Obcych w Warszawie, Warszawa, Poland.

Wabnic, B. (2015). Dziedzictwo kulinarne Dolnego Śląska i jego znaczenie w turystycznej promocji regionu [Culinary heritage of the Lower Silesia and its significance in the tourist promotion of the region]. Bachelor thesis, Wyższa Szkoła Bankowa Wrocław, Poland.

Widawski, K., \& Oleśniewicz, P. (2014). Wydarzenia kulinarne jako szansa na turystyczna aktywizację regionu [Culinary events as an opportunity to activate regional tourism]. Gospodarka Rynek Edukacja, 15(2), 33-37, (in Polish).

Wolf, E. (2001). Culinary tourism: a tasty economic proposition. http://www.culinarytourism.org

Woźniczko, M., Jędrysiak, T., \& Orłowski, D. (2015). Turystyka kulinarna [Culinary tourism]. Polskie Wydawnictwo Ekonomiczne, Poland.

Woźniczko, M., \& Orłowski, D. (2017). Wydarzenia jako urozmaicona forma turystyki kulinarnej na przykładzie Festiwalu „Europa na widelcu” we Wroctawiu [Events as a Culinary Tourism Varied Form on the Example of the Festival "Europe on the Fork" in Wroclaw]. Zeszyty Naukowe Uczelni Vistula 54(3) Turystyka III, 125-154, (in Polish).

Yousafab, S., \& Xiuchenga, F. (2018). Halal culinary and tourism marketing strategies on government websites: A preliminary analysis. Tourism Management, 68, 423-443. https://doi:10.1016/j.tourman.2018.04.006.

Žuromskaitė, B. (2009). Rozwój turystyki kulinarnej na Litwie [The development of culinary tourism in Lithuania]. Turystyka Kulturowa, 12, 21-32 (in Polish).

Žuromskaitè, B., \& Leišienè, N. (2014). Możliwości rozwoju turystyki kulinarnej na Żmudzi [Culinary Tourism Possibility Development in Samogitia]. Turystyka i Rozwój Regionalny, 1, 155-166, (in Polish).

*** European Network of Regional Culinary Heritage (2018). Numbers of members and approved regions of the European Network of Regional Culinary Heritage. accessed 25.10.2015, 17.11.2018. http://www.culinary-heritage.com/regions.asp

*** Kalendarz Imprez Kulinarnych Dolnego Śląska [Lower Silesia Culinary Events Calendar] The Marshal's Office of Lower Silesian Voivodeship, 2014, 2015, 2016, 2017, (in Polish).

*** Lower Silesian Tourist Organization (2018), Smaki Dolnego Ślaska [Lower Silesian Tastes]. accessed 04.09.2018, (in Polish). http://smakidolnegoslaska.pl/en/home/

*** Ministry of Agriculture (2017). Lista produktów tradycyjnych [List of Traditional Products]. accessed 15.10.2017, (in Polish). http://www.minrol.gov.pl/ pol/Jakosc-zywnosci/Produkty-regionalne-i-tradycyjne/Lista-produktow-tradycyjnych/woj-dolnoslaskie

*** Ministry of Agriculture and Rural Development (2020). Lista produktów tradycyjnych [List of Traditional Products], accessed 03.11.2020, (in Polish). https://www.gov.pl/web/rolnictwo/woj-dolnoslaskie

*** National Network of Educational Farms, accessed 02.01.2018. http://www.zagrodaedukacyjna.pl

*** Polish Chamber of Regional and Local Products (2017). Laureaci konkursu "Perta" ["Pearl" award winners]. accessed 15.10.2017, (in Polish). http://www.produktyregionalne.pl/nkd.html

*** Szlakiem Dobrego Smaku (2013) [Following the Trail of Good Taste], Agricultural Market Agency, Poland.

*** Ustawa z dnia 17 grudnia $2004 \mathrm{r}$. o rejestracji i ochronie nazw i oznaczeń produktów rolnych i środków spożywczych oraz o produktach tradycyjnych [Act of 17 December 2004 on the registration and protection of names and designations of agricultural products and foodstuffs, and on traditional products, Journal of Laws of 2005 No. 10, item 68]. 